\title{
Small but tough:What can ecophysiology of croaking gourami Trichopsis vittata (Cuvier, I 83I) tell us about invasiveness of non-native fishes in Florida?
}

\author{
Pamela J. Schofield', Jessica M. Schulte' \\ I US Geological Survey, 7920 NW 71st Street, Gainesville, FL 32653, USA \\ Corresponding author: Pamela J. Schofield (pschofield@usgs.gov)
}

Academic editor: E.García-Berthou| Received 8 May 2015 | Accepted 27 September 2015 | Published 8 January 2016

Citation: Schofield PJ, Schulte JM (2016) Small but tough: What can ecophysiology of croaking gourami Trichopsis vittata (Cuvier, 1831) tell us about invasiveness of non-native fishes in Florida?. NeoBiota 28: 51-65. doi: 10.3897/ neobiota.28.5259

\begin{abstract}
Trichopsis vittata (Cuvier, 1831) is a small, freshwater gourami (Fam: Osphronemidae) native to southeast Asia. It was first detected in Florida in the 1970s and seems to have persisted for decades in a small area. In this study, we documented T. vittata's ecophysiological tolerances (salinity and low-temperature) and qualitatively compared them to published values for other sympatric non-native species that have successfully invaded much of the Florida peninsula. Trichopsis vittata survived acute salinity shifts to 16 psu and was able to survive up to 20 psu when salinity was raised more slowly ( 5 psu per week). In a cold-tolerance experiment, temperature was lowered from $24^{\circ} \mathrm{C}$ at $1{ }^{\circ} \mathrm{C} \mathrm{hr}^{-1}$ until fish died. Mean temperature at death (i.e., lower lethal limit) was $7.2^{\circ} \mathrm{C}$. Trichopsis vittata seems as tolerant or more tolerant than many other sympatric non-native fishes for the variables we examined. However, T. vittata is the only species that has not dispersed since its introduction. Species other than $T$. vittata have broadly invaded ranges, many of which include the entire lower third of the Florida peninsula. It is possible that tolerance to environmental parameters serves as a filter for establishment, wherein candidate species must possess the ability to survive abiotic extremes as a first step. However, a species' ability to expand its geographic range may ultimately rely on a secondary set of criteria including biotic interactions and life-history variables.
\end{abstract}

\section{Keywords}

Trichopsis, ecophysiology, low-temperature tolerance, salinity tolerance, invasiveness 


\section{Introduction}

Destructive (sometimes catastrophic) ecological impacts have been attributed to the introduction and establishment of non-native fishes across the globe (Canonico et al. 2005; Pelicice and Agostinho 2009; Vitule et al. 2009). However, the severity of negative consequences of non-native fish invasions varies greatly amongst taxa. Variation in the ability of species to establish and spread (i.e., 'invasiveness' sensu Rejmánek et al. 2002) has provided clues to underlying ecological attributes correlated with invasiveness (García-Berthou 2007). Understanding the characteristics associated with invasiveness is especially important in predicting potential establishment and spread of newly introduced species or those considered a threat for introduction. Most studies aimed at discriminating ecological features of invasive species quantify, collate and report life-history, ecophysiological, and other data for species that have become invasive (Kolar and Lodge 2002; García-Berthou 2007). Less abundant are data on species that were introduced and died out over time, or those that were introduced and established but did not become invasive. Data on those non-invasive species can be difficult to obtain when species were not intentionally introduced (e.g., via stocking). Population dynamics of fishes that were not introduced intentionally (e.g., aquaculture escapes) may not be closely monitored. Nonetheless, the fate of these populations is important as they may provide clues to allow researchers to be able to identify characteristics unique to invasive fishes from those shared between invasive and non-invasive species.

In Florida, there are dozens of non-native fish species that have established and spread widely within the state, especially in the southern half of the peninsula. However, a few species have established but remain localised (Shafland et al. 2008; USGSNAS 2014). Croaking gourami Trichopsis vittata (Cuvier, 1831) was first collected in 1978 and was considered extirpated in the 1990s; however, a localised population was rediscovered in 2013 (Schofield and Pecora 2013; Fig. 1). The species may have persisted in a relatively small area for several decades where it escaped detection. Failure of a species to spread widely after establishment may be due to many factors, such as ecophysiological intolerance or biotic interactions with predators and/or competitors. Little is known regarding the ecophysiology of $T$. vittata, other than the fact that it is an air-breather, making it capable of living in anoxic waters. Other ecophysiological attributes (e.g., tolerance to salinity, extreme temperature) were unknown before this report. Herein, we investigate two ecophysiological parameters for $T$. vittata thought to be conducive to invasiveness in Florida (cold- and salinity-tolerance). We compare those (along with hypoxia-tolerance) to published reports for other non-native fishes with much larger geographic ranges within the State. We ask: Can T. vittata's small geographic range be explained by its relative lack of ecophysiological 'toughness' (i.e., ability to withstand environmental extremes)? In other words, are fishes more tolerant to cold temperatures, low oxygen and salinity predicted to have larger invasive geographic ranges? We hypothesised that $T$. vittata's small non-native range could be related to a lack of tolerance of ecophysiological variables, and expected it to be less tolerant to environmental variables than sympatric non-native fishes with large ranges. 

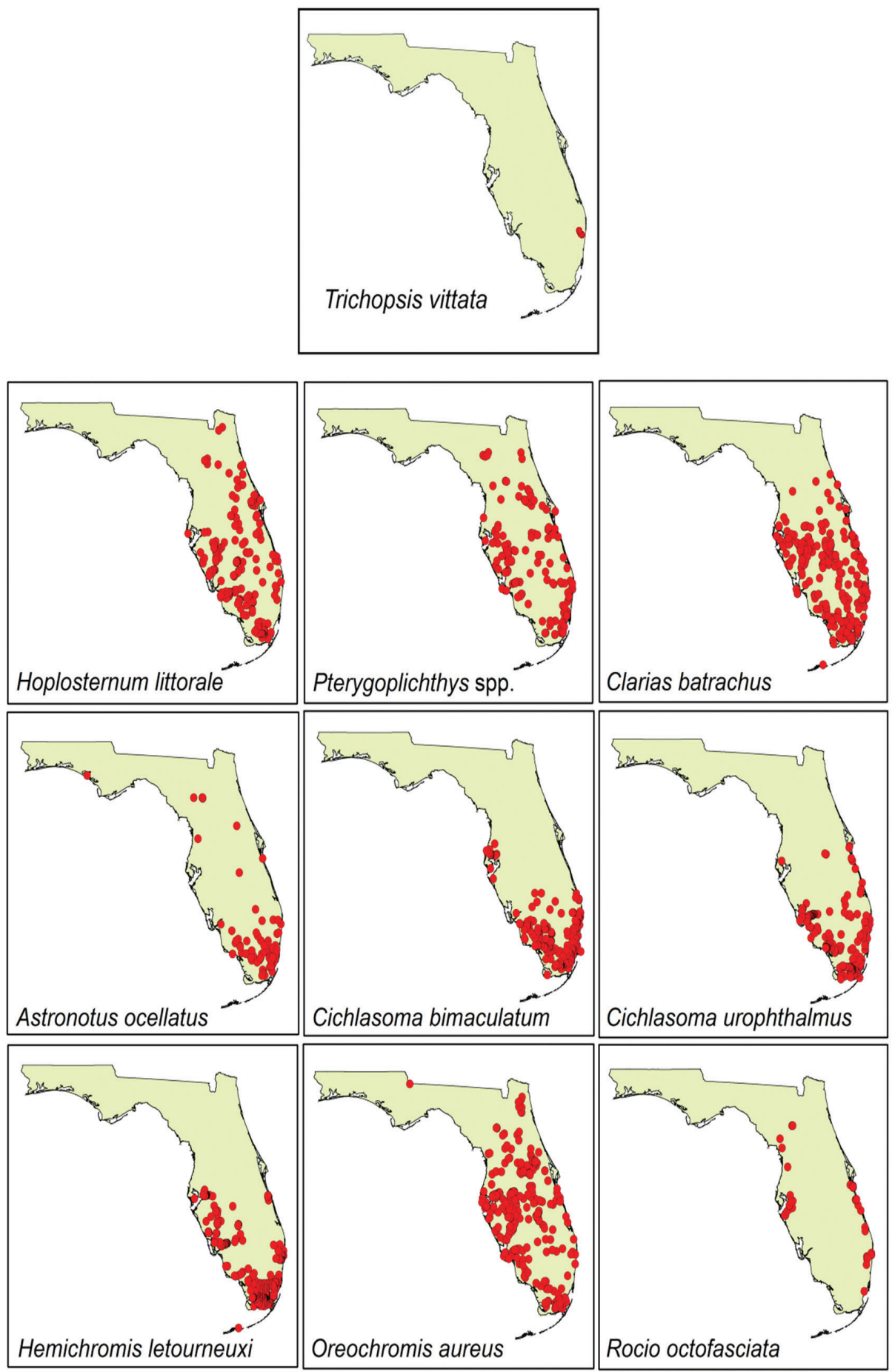

Figure I. Geographic range of selected non-native fishes in Florida. Occurrence data (red dots) are from USGS-NAS (2014). 


\section{Methods}

Specimens of T. vittata were collected with dip nets in March and April 2014, from Loxahatchee National Wildlife Refuge, Florida, USA. Fish were transported to the USGS laboratory in Gainesville, Florida within 48 hours of capture. Upon arrival, fish were treated with Pond Rid-Ich ${ }^{\oplus}$ Plus $^{\mathrm{TM}}$ (Kordon LLC, Hayward, CA, USA) and erythromycin antibiotic. In the laboratory, fish were held indoors in $380 \mathrm{~L}$ fiberglass tanks with aerated well water $\left(0.2 \mathrm{psu}\right.$, hereafter termed " 0 " psu, $\left.21-25^{\circ} \mathrm{C}\right)$ and were fed daily with commercial flake food. Individuals were held in these conditions for about one month before experiments began. Before each experiment, fish were measured $( \pm 0.1 \mathrm{~cm}$ total length [TL]), weighed $( \pm 0.1 \mathrm{~g})$ and placed into individual plastic bins $(17 \times 14 \times 11 \mathrm{~cm})$ filled with $8 \mathrm{~cm}$ of well water. Bins were equipped with small plastic plants, lids to prevent escape and were blinded on three sides to prevent fish from seeing each other. Because gourami are obligate air breathers, no air was provided except for the low-temperature tolerance experiment, where an airstone was placed in each bin to aid in mixing of the water for even temperature distribution throughout the bin. For both salinity experiments, fish were kept in individual bins inside a temperature-controlled room set at $26 \mathrm{C}$ for the duration of the experiments. Salt water was pre-mixed to various salinities using well water and aquarium salt (Crystal Sea Marinemix, Marine Enterprises International, Baltimore, MD, USA) before water changes using YSI Professional Plus Multiparameter meter (YSI Inc., Yellow Springs, Ohio, USA; \pm 0.05 psu). For all experiments, when death was confirmed, water temperature was measured using a hand-held digital thermometer $\left(\mathrm{EXTECH}^{\bullet}\right.$ waterproof thermometer model \#39240, EXTECH Instruments ${ }^{\circ}$, Nashua, NH, USA). Individual fish were used only once in one experiment (low-temperature tolerance, chronic salinity-tolerance or acute salinity-tolerance).

\section{Low temperature tolerance}

The low-temperature tolerance experiment was conducted in April 2014 inside an environmental chamber in which temperature could be controlled by continuously decreasing the air temperature at a constant (i.e., linear) rate. Two endpoints were determined: loss of equilibrium and death (i.e., lower lethal limit). Loss of equilibrium (LOE) was defined as the fish's inability to right itself after being gently prodded, and death was defined as the extended lack of movement by the fish after it was gently prodded while in the water. Twenty-five fish were used and were not fed during the duration of the experiment. Fish were placed in the environmental chamber in individual bins and left undisturbed for 72 hours at $24^{\circ} \mathrm{C}$ to acclimate. The experiment began by decreasing the air temperature by $1{ }^{\circ} \mathrm{C} \mathrm{hr}^{-1}$ to produce an equivalent decline in water temperature. Control fish $(\mathrm{n}=5)$ were immediately moved from the environmental chamber to a stable "warm room" at $24^{\circ} \mathrm{C}\left( \pm 1^{\circ} \mathrm{C}\right)$ until the end of the testing period, when all experimental fish $(\mathrm{n}=20)$ had succumbed to death. Each hour, air temperature in the chamber was manually adjusted to produce a constant decrease of water 
temperature at the rate of $1{ }^{\circ} \mathrm{C}$ per hour. Temperature of each bin was measured with a hand-held digital thermometer every 20 minutes. All fish were checked for LOE and death every 20 minutes; time and temperature were recorded when LOE and death were confirmed.

\section{Chronic salinity tolerance}

An initial pilot study was conducted on $n=20$ individuals to establish a general range of salinity tolerance and determine what experimental salinity levels would be used for the experiment. For the chronic salinity tolerance experiment, fish were allocated randomly to one of five treatments $(0$ [control] $=8$ replicates, 20 psu $=11$ replicates, 22.5 psu $=12$ replicates, $25 \mathrm{psu}=12$ replicates, $27.5 \mathrm{psu}=13$ replicates $)$. Fish were held initially for 48 hours in well water after which salinities were gradually increased at a rate of 2.5 psu every 2-3 days (5 psu per week) until fish reached the predetermined target salinity. Once the last experimental fish reached its target salinity, all fish remained in their respective salinities for an additional 30 days or until death. Fish reached their target salinities in a staggered (time-wise) fashion; however, each time the salinities were changed in one or more of the treatments, water changes were performed for all of the fish (including controls) to maintain similarity of handling across treatments. Fish were fed twice per week with a mixture of flake food and pellets on days before water changes. Fish were checked 1-2 times per day, seven days per week for death.

\section{Acute salinity tolerance}

To determine how $T$. vittata responded to acute salinity changes, fish were transferred directly from well water $(0 \mathrm{psu})$ into various salinity treatments: 0 [control] $=8$ replicates, $14,16,18,20 \mathrm{psu}=10$ replicates each. Similar to the chronic-salinity tolerance experiment, values for salinity treatments were derived from a pilot study. After being transferred to their respective treatments, fish were left in bins for seven days or until death. Fish were checked for mortalities every hour for the first six hours and then once per day for the remainder of the experiment.

\section{Analyses}

Cold-tolerance of $T$. vittata was compared to published values for other previously tested non-native fishes. We statistically compared four species that are sympatric with $T$. vittata (e.g., are found in Loxahatchee NWR) and are widely distributed across south Florida (Cichlasoma bimaculatum [Linnaeus 1758], Cichlasoma urophthalmus [Günther 1862], Hoplosternum littorale [Hancock 1828], Hemichromis letourneuxi Sauvage 1880; Fig. 1). These species were tested in our laboratory using the same technique, acclima- 
tion temperature, experimental equipment and rate of temperature decrease used here for T. vittata (Schofield et al. 2010; Schofield and Huge 2011; Schofield unpub. data). We only compared data for individuals tested in freshwater and acclimated to $24{ }^{\circ} \mathrm{C}$. Mean temperature at death (lower lethal limit) for these species was compared with one-way analysis of variance (ANOVA), and Dunnett's T3 post-hoc test was used to discriminate homogeneous subsets. Levene's test was used to test for heteroscedasticity.

One-way ANOVA was used to compare fish mass among salinity treatments, and Levene's test was used to check for heteroscedasticity. Life expectancy was estimated with the Kaplan-Meier product-limit estimator (Kaplan and Meier 1958) and the log-rank test was used to compare survivorship curves (Savage 1956; Cox and Oakes 1984). For the acute-salinity challenge, all treatments began at the same time (time $=0$ ). However, for the chronic-salinity experiment, fish reached their target salinities sequentially (i.e., staggered over time). Thus, for the chronic-salinity experiment the day the fish reached their target salinity was designated as time $=0$ for that treatment. We set our alpha level for statistical significance at 0.05 . All data were analysed using SPSS version 13.0 .

\section{Results}

Environmental variables measured while collecting T. vittata on several occasions (including fish used in this experiment) are provided in Table 1. Trichopsis vittata used in the cold-tolerance study averaged $0.73 \mathrm{~g}(+0.67$ standard deviation [SD]; range 0.20-3.00 g; $\mathrm{n}=25)$, and $3.7 \mathrm{~cm}$ TL (+0.99 SD; range $2.5-5.9 \mathrm{~cm})$. Fish lost equilibrium at $10.2{ }^{\circ} \mathrm{C}\left(+0.68 \mathrm{SD}\right.$; range $\left.8.2-11.2^{\circ} \mathrm{C}\right)$ and died at $7.2{ }^{\circ} \mathrm{C}(+0.68 \mathrm{SD}$; range $6.4-8.8^{\circ} \mathrm{C}$ ). Trichopsis vittata was the second-most cold-tolerant species tested (after $H$. littorale), and exhibited greater tolerance to low temperatures than all cichlids (oneway ANOVA $\mathrm{F}=49.46$, df = 4, $\mathrm{P}<0.001$, Fig. 2).

For the chronic salinity-tolerance experiment, fish mass averaged $0.93 \mathrm{~g}(+0.28$ $\mathrm{SD}$; range $0.30-1.5 \mathrm{~g} ; \mathrm{n}=56)$ and mean $\mathrm{TL}$ was $4.2 \mathrm{~cm}(+0.55 \mathrm{SD}$; range 3.0-5.1 $\mathrm{cm} ; \mathrm{n}=56$ ). Fish mass did not vary significantly by treatment (one-way ANOVA $\mathrm{F}=$ 0.11 , $\mathrm{df}=4, P=0.58)$. At the end of the experiment, survival was $100 \%$ at the control salinity (0 psu), 63\% at 20 psu, 25\% at 22.5 psu, and $8 \%$ at 25 psu (Fig. 3a). All fish at 27.5 psu died by the $24^{\text {th }}$ day after reaching their 27.5 psu salinity goal. Because the majority of the data for the 20 psu treatment was censored (i.e., the majority of fish in this treatment survived the challenge), it was not possible to compute a survival estimate. Mean (95\% Confidence Interval [CI]) survival estimates for other treatments are: 18 days (11-25) at 22.5 psu, 10 days (4-16) at 25 psu, 7 days (3-11) at 27.5 psu. All treatments were significantly different from the control except 20 psu (although the $P$-value was close to significance; log-rank statistic $=3.41 ; P=0.065$ )

The mean mass of fish used in the acute salinity-tolerance experiment was $0.81 \mathrm{~g}(+$ $0.31 \mathrm{SD}$; range $0.30-1.6 \mathrm{~g} ; \mathrm{n}=48)$ and mean length was $4.1 \mathrm{~cm}$ TL $(+0.54 \mathrm{SD}$; range $3.0-5.2 \mathrm{~cm}$ ). Fish mass did not vary significantly by treatment (one-way ANOVA F = 
0.98 , df $=4, P=0.43)$. After the acute salinity change, $T$. vittata at 20 psu exhibited $60 \%$ mortality within the first four hours and 100\% mortality within the first six hours (mean survival estimate $=4.5 \mathrm{hrs} ; 4.1-4.9 \mathrm{hrs} 95 \% \mathrm{CI}$ ). The 18 psu treatment group displayed $70 \%$ mortality after 24 hours, with no fish surviving longer than 48 hours (mean survival estimate $=30$ hrs; 21.5-38.5 95\% CI; Fig. 3b). At salinities of 0 and 14 , survival was $100 \%$ and at 16 psu, it was $90 \%$ at the end of the experiment. No survival estimates were calculated for these three treatments as survival was so high (and subsequently most of the data were censored). Survival was equivalent for 0 and 14 psu (100\%) and did not differ significantly between 0 and 16 psu (log-rank statistic $=0.80 ; P=0.37)$ nor 14 and $16(\log$-rank statistic $=1.00 ; P=0.32)$.

Table I. Environmental variables measured while collecting Trichopsis vittata on several occasions from Loxahatchee National Wildlife Refuge. Fish for experiments in this report were collected in March and April 2014. N/A = Not Available.

\begin{tabular}{c|c|c|c|c}
\hline Collection date & Temperature $\left({ }^{\circ} \mathbf{C}\right)$ & Salinity $(\mathbf{p s u})$ & Dissolved Oxygen $\left(\mathbf{m g ~ L}^{-1}\right)$ & $\mathbf{p H}$ \\
\hline 7 March 2014 & 20.6 & 0.07 & 0.87 & N/A \\
\hline 23 April 2014 & 25.1 & 0.21 & 0.74 & 7.18 \\
\hline 24 April 2014 & 21.8 & 0.22 & 0.67 & 7.12 \\
\hline 31 March 2015 & 21.2 & 0.17 & 3.14 & 7.27 \\
\hline
\end{tabular}

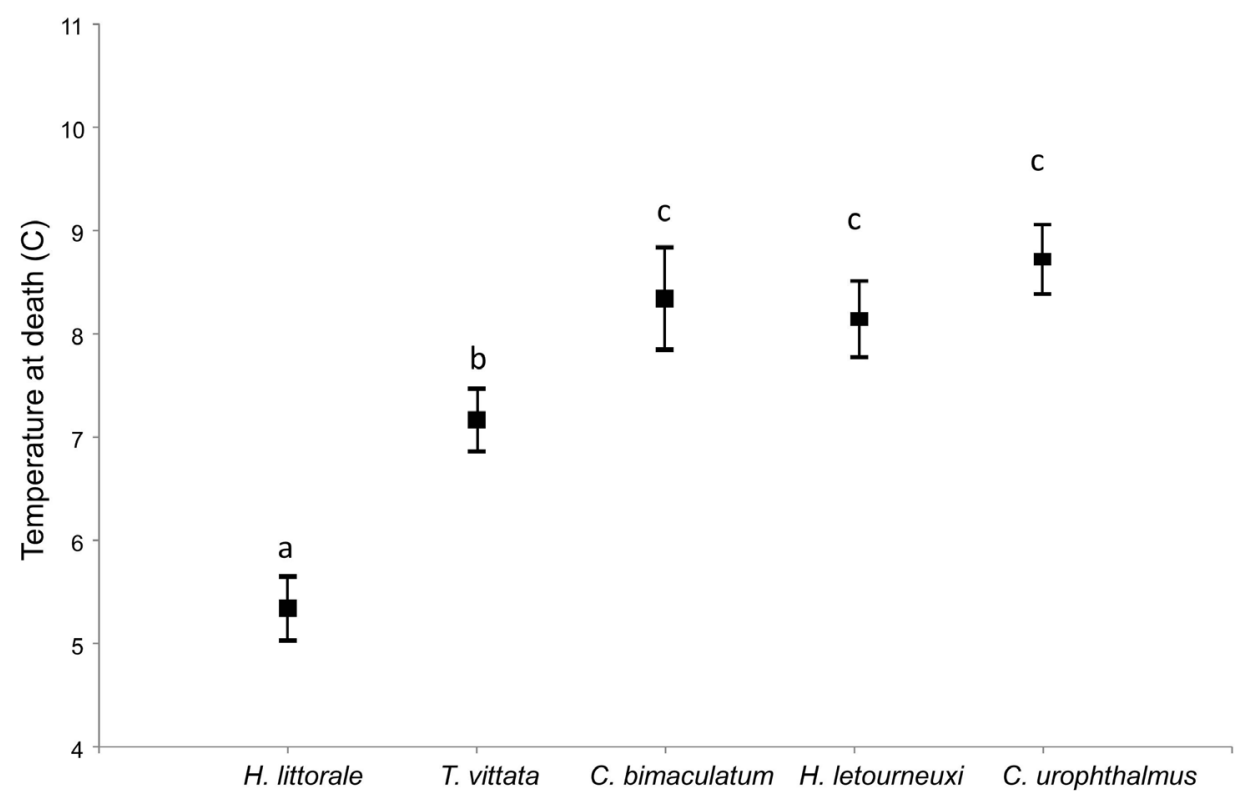

Figure 2. Mean temperature $(+2 \mathrm{SE})$ at which fishes died in cold-temperature tolerance experiments (i.e., lower lethal limit). Letters denote significant differences (one-way ANOVA with Dunnett's T3 post-hoc test; see text for details). References for data sources are given in Table 2. 

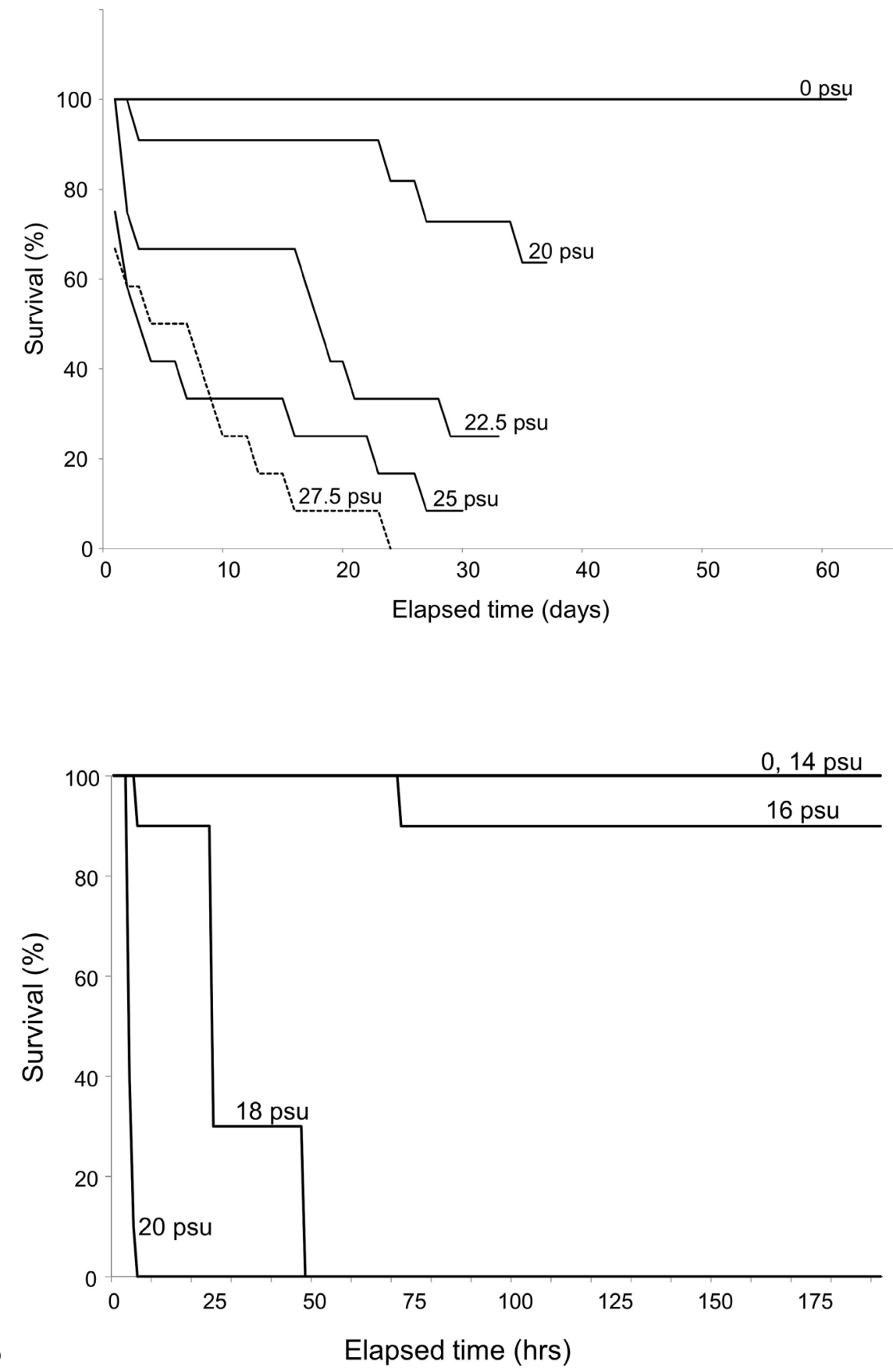

Figure 3. Salinity tolerance of T. vittata. Results from $\mathbf{a}$ chronic and $\mathbf{b}$ acute salinity-tolerance trials. 


\section{Discussion}

Trichopsis vittata has been known from Florida since the 1970s, when an established population was discovered within $10 \mathrm{~km}$ of its current range (Courtenay et al. 1984, 1986; Schofield and Pecora 2013). Its introduction source is unknown; however, at the time of discovery it was speculated that it had escaped from nearby aquarium fish farms (Courtenay et al. 1984, 1986). Over time, the species was thought to have been extirpated (Shafland 1996; Shafland et al. 2008) until its recent rediscovery (Schofield and Pecora 2013). No fish-monitoring programmes cover urban areas in this region of Florida, so it is unclear how long the fish was established before its recent collection at Loxahatchee NWR. Furthermore, it is unclear whether the species had died out and was subsequently re-introduced or whether this is a remnant population. Nevertheless, its ability to persist in this small range for many decades makes it an interesting candidate for study. The purpose of this investigation was to document ecophysiological attributes of the species and qualitatively compare them to sympatric species, to see if perhaps reduced ecophysiological tolerance might be related to the lack of geographic expansion.

In general, our hypothesis (low ecophysiological toughness $\approx$ small geographic range) was not supported. Ecophysiological traits of T. vittata and nine sympatric nonnative fishes known from Florida freshwaters were tabulated (Table 2). Sympatric nonnative fishes include ones that have been established since the 1950s (Pterygoplichthys spp., Astronotus ocellatus [Agassiz 1831], Cichlasoma bimaculatum), 1960s (Clarias batrachus [Linnaeus 1758], Hemichromis letourneuxi, Oreochromis aureus [Steindachner 1864]), 1970s (Rocio octofasciata [Regan 1903]), 1980s (C. urophthalmus) and 1990s (H. littorale; see Shafland et al. 2008, Schofield and Loftus 2014 for establishment timelines; Table 2, Fig. 1). Tolerance of these species to hypoxia and low-temperatures was graphically compared (Fig. 4). Trichopsis vittata was more tolerant of cold than many sympatric non-native fishes, leading us to believe it could tolerate habitats north of its current range; however, it has not expanded its range in any direction. Furthermore, its ability to breathe atmospheric air (via a labyrinth organ) imparts an ability to live indefinitely in water devoid of oxygen. It should be able to tolerate a variety of marginal habitats such as shallow pools, vegetation-choked swamps, and habitats with low light levels as it does at Loxahatchee NWR and in its native range (Rainboth 1996). As for salinity, we documented herein that T. vittata was tolerant to acute shifts in salinity to $16 \mathrm{psu}$ and gradual shifts to $20 \mathrm{psu}$. This level of tolerance is lower than published values for most cichlids, but greater than many non-cichlid invasive fishes (Table 2). Nonetheless, it is a species that is probably tolerant enough to occupy freshwater tidal or low-salinity estuarine areas, or use them as salt bridges for dispersal. Yet it has not moved into coastal areas even though the current population is less than 20 $\mathrm{km}$ from the Atlantic coast. In summary, while T. vittata seems as tough or tougher than other sympatric non-native fishes (in terms of ecophysiology; Table 2, Fig. 4), it has not been able to capitalise on these advantages and expand its geographic range as the others have. It is possible that tolerances to environmental parameters are not directly correlated with geographic range for this group of species, but instead serve as 


\begin{tabular}{|c|c|c|c|c|c|c|c|c|c|c|}
\hline 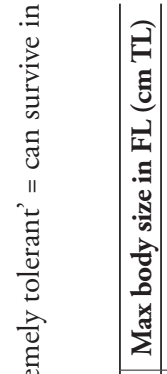 & 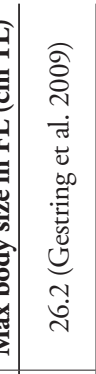 & 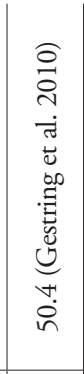 & 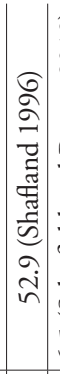 & 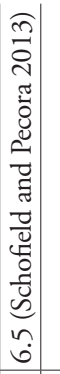 & 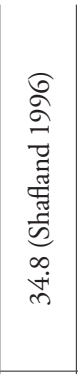 & 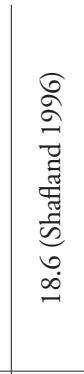 & 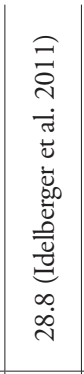 & 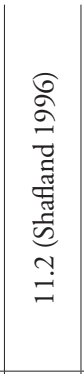 & 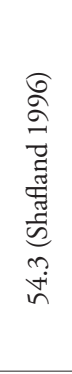 & 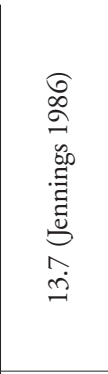 \\
\hline 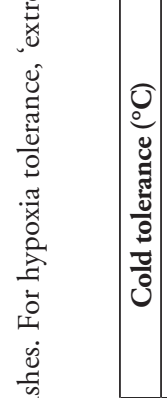 & 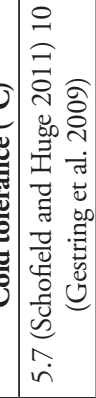 & 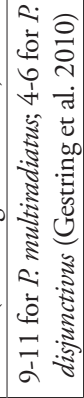 & 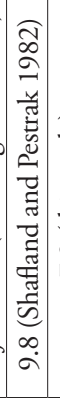 & 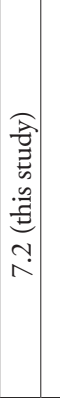 & 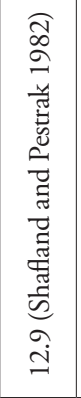 & 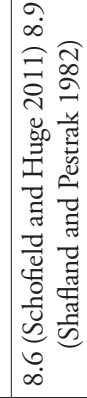 & 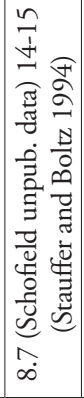 & 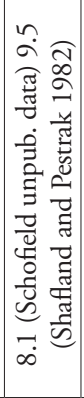 & 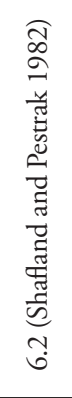 & 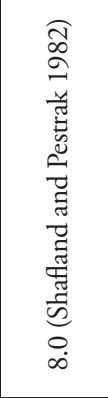 \\
\hline 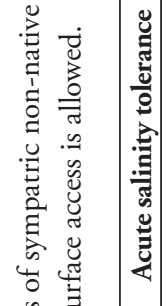 & 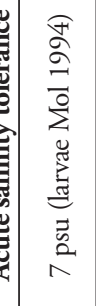 & 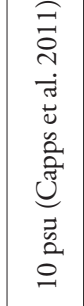 & 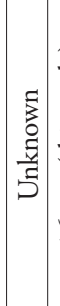 & 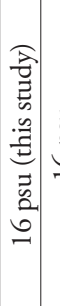 & 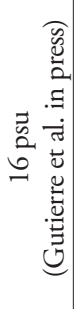 & 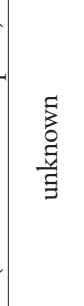 & 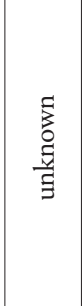 & 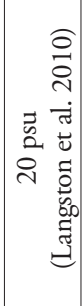 & $\begin{array}{l}\mathbb{E} \\
0 \\
\vdots \\
\Xi \\
\Xi\end{array}$ & 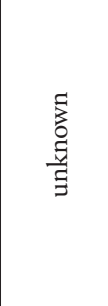 \\
\hline 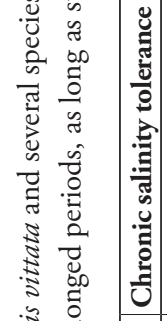 & 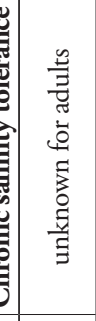 & $\begin{array}{l}\frac{5}{3} \\
\vdots \\
\vdots \\
\Xi \\
\Xi\end{array}$ & $\begin{array}{l}0 \\
\vdots \\
0 \\
\vdots \\
\vdots \\
\vdots\end{array}$ & 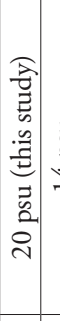 & 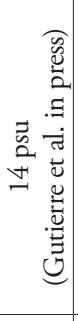 & 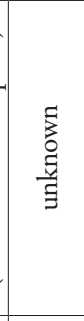 & 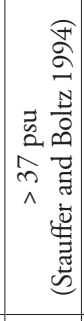 & 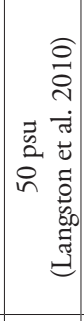 & 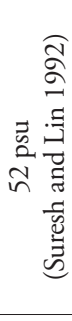 & 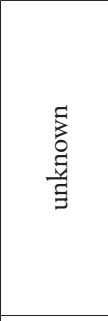 \\
\hline 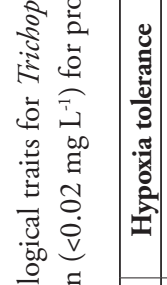 & 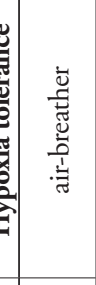 & 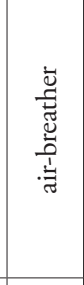 & 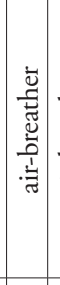 & 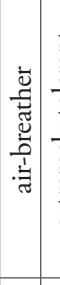 & 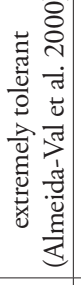 & 泀 & 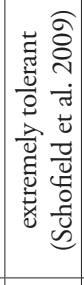 & 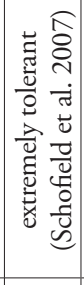 & 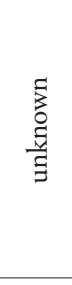 & 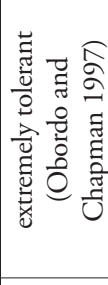 \\
\hline 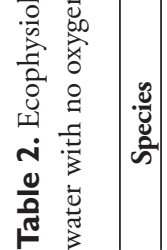 & 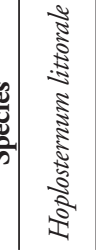 & 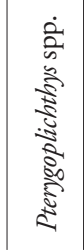 & 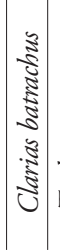 & $\mid$ & 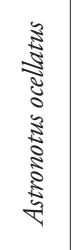 & 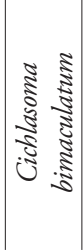 & 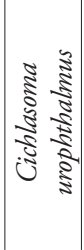 & 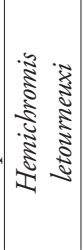 & 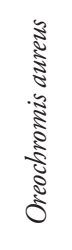 & $\begin{array}{l}3 \\
3 \\
0 \\
0 \\
8 \\
8 \\
8 \\
8 \\
8 \\
8\end{array}$ \\
\hline
\end{tabular}




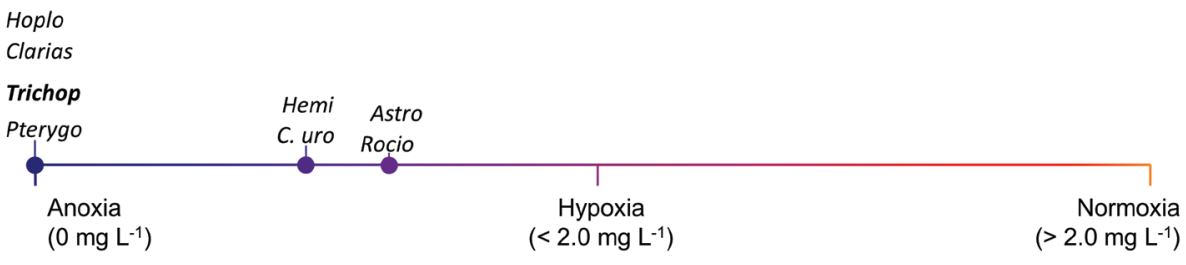

Low-oxygen tolerance

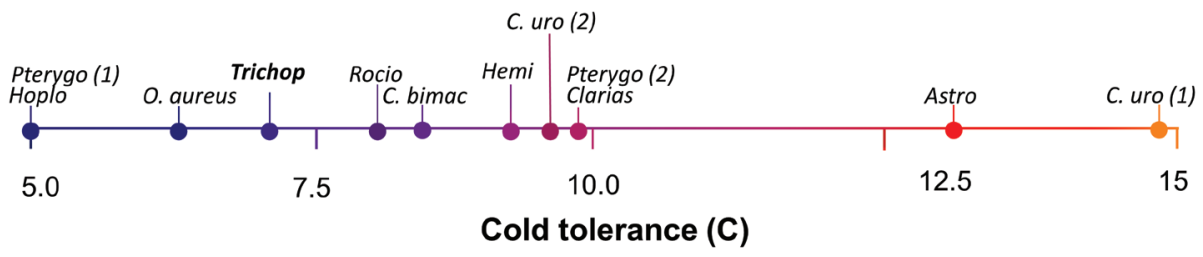

More tolerant

Less tolerant

\section{Relative tolerance}

Figure 4. Graphic representation of relative ecophysiological 'toughness' for T. vittata and sympatric non-native fishes. References for cold and low-oxygen tolerance are given in Table 2. Two values are presented for cold tolerance of C. urophthalmus as two separate reports provided dissimilar data (Table 2). Two values are given for Pterygoplichthys spp. corresponding to two different species (Table 2). "O. aureus" = Oreochromis aureus; "Pterygo" = Pterygoplichthys spp.; "Hoplo" = Hoplosternum littorale; "Clarias" = Clarias batrachus; "Trichop" = Trichopsis vittata; "Hemi" = Hemichromis letourneuxi; "C. uro" = Cichlasoma urophthalmus; "Astro" = Astronotus ocellatus; "Rocio" = Rocio octofasciata; "C. bimac" = Cichlasoma bimaculatum.

a filter for establishment, wherein candidate species must possess the ability to survive abiotic extremes as a first step (Peterson et al. 2004). Once fish have passed through this step, invasiveness (at least in terms of geographic spread) may ultimately rely on a secondary set of criteria including biotic interactions and life-history variables.

The intriguing combination of high abiotic tolerance and low invasiveness in T. vittata may support the biotic-abiotic constraining hypothesis (Quist et al. 2003), wherein abiotic environmental variables structure population levels until overridden by biotic ones (e.g., predation, competition). For example, Quist et al. (2003) showed that variation in walleye Stizostedion vitreum (now Sander vitreus [Mitchill, 1818]) populations in Kansas reservoirs could be explained by environmental variables until a critical threshold for biotic interactions was reached. In that case, once the density of a predator (Pomoxis annularis Rafinesque, 1818) was exceeded, then biotic interactions overrode abiotic influences and $S$. vitreum population dynamics were related to $P$. annularis density. Similarly, Weber and Brown (2011) showed that variation in density of native 
fish populations were related to environmental variables until a threshold density of Cyprinus carpio Linnaeus, 1758 was reached and then biotic interactions overrode abiotic ones. As for T. vittata, future research on its co-occurrence with competitors and predators may shed light on the relative influences of abiotic versus biotic constraints.

There are many other factors that could explain the lack of geographic range expansion for T. vittata. Some of the most obvious candidates include body size, diet and their interaction. Trichopsis vittata is smaller than other sympatric non-native fishes and occupies a relatively low position on the predation spectrum (i.e., primarily consumes small invertebrates; Rainboth 1996). This combination of attributes separates T. vittata from the other non-native fishes that are either: 1) large-bodied species that consume benthic algae and detritus (e.g., Pterygoplichthys spp., O. aureus) or 2) largeto medium-sized fish predators (cichlids, C. batrachus). One species that does not fit this pattern is H. letourneuxi, which consumes both invertebrates and fish and does not reach a large body size (Table 2), yet is extremely invasive (Kline et al. 2013; Fig. 1). Protection from bony dermal plates may confer an additional advantage to catfishes (H. littorale, Pterygoplichthys spp.) and bolster their ability to spread geographically. Other factors that could affect invasiveness include biotic resistance (e.g., Thompson et al. 2012), specific requirements for egg/larval development or nesting, multiple introductions (Collins et al. 2002), predation susceptibility (e.g., Rehage et al. 2009) and propagule pressure (Colautti et al. 2006). Application of modern modelling techniques may allow researchers to identify which variables are most important for an invader's success (and spread) and the critical thresholds for those variables (e.g. Kolar and Lodge 2002).

\section{Acknowledgments}

Support for this project was provided by the US Geological Survey, Invasive Species Programme and the Southeast Ecological Science Center. We thank D. Pecora, S. M. Gutierre and M. Brown for their assistance with various aspects of fish and data collection. A. Benson kindly created the maps. S. Ruessler and W. Hyde provided generous assistance with laboratory facilities. M. Hunter and W. Loftus provided comments on an earlier version of the manuscript. Fish were collected under Special Use Permit B14005 from ARM Loxahatchee Wildlife Refuge. All procedures were in compliance with Institutional Animal Care and Use Committee regulations (approved protocol USGS/ SESC 2014-10). Any use of trade, product or firm names is for descriptive purposes only and does not imply endorsement by the US Government.

\section{References}

Almeida-Val VM, Val AL, Duncan WP, Souza FCA, Paula-Silva MN, Land S (2000) Scaling effects on hypoxia tolerance in the Amazon fish Astronotus ocellatus (Perciformes: 
Cichlidae): contribution of tissue enzyme levels. Comparative Biochemistry and Physiology Part B: Biochemistry and Molecular Biology 125: 219-226. doi: 10.1016/S03050491(99)00172-8

Canonico GC, Arthington A, McCrary JK, Thieme ML (2005) The effects of introduced tilapias on native biodiversity. Aquatic Conservation: Marine and Freshwater Ecosystems 15: 463-483. doi: 10.1002/aqc.699

Capps KA, Nico LG, Mendoza-Carranza M, Arévlo-Frías W, Ropicki AJ, Heilpern SA, Rodiles-Hernández R (2011) Salinity tolerance of non-native suckermouth armoured catfish (Loricariidae: Pterygoplichthys) in south-eastern Mexico: implications for invasion and dispersal. Aquatic Conservation: Marine and Freshwater Ecosystems 21: 528-540. doi: 10.1002 /aqc. 1210

Colautti RI, Grigorovich IA, MacIsaac HJ (2006) Propagule pressure: a null model for biological invasions. Biological Invasions 8: 1023-1037. doi: 10.1007/s10530-005-3735-y

Collins TM, Trexler JC, Nico LG, Rawlings TA (2002) Genetic diversity in a morphologically conservative invasive taxon: multiple introductions of swamp eels to the southeastern United States. Conservation Biology 16: 1024-1035. doi: 10.1046/j.1523-1739.2002.01182.x

Courtenay WR Jr, Hensley DA, Taylor JN, McCann JA (1984) Distribution of exotic fishes in the continental United States. In: Courtenay WR Jr, Stauffer JR Jr (Eds) Distribution, Biology and Management of Exotic Fishes. Johns Hopkins University Press, Baltimore, MD, 41-77.

Courtenay WR Jr, Hensley DA, Taylor JN, McCann JA (1986) Distribution of exotic fishes in North America. In: Hocutt CH, Wiley EO (Ed.) The Zoogeography of North American Freshwater Fishes. John Wiley and Sons, New York, NY, 675-698.

Cox DR, Oakes D (1984) Analysis of survival data. Monographs on statistics and applied probability. Chapman and Hall, New York, NY.

García-Berthou E (2007) The characteristics of invasive fishes: what has been learned so far? Journal of Fish Biology 71 (Supplement D): 33-55. doi: 10.1111/j.1095-8649.2007.01668.x

Gestring KB, Shafland PL, Stanford MS, Eisenhauer RL (2009) Status and selected life history attributes of the illegally introduced Brown Hoplo (Hoplosternum littorale) in Florida. Florida Scientist 72: 37-47.

Gestring KB, Shafland PL, Stanford MS (2010) Status of the exotic Orinoco sailfin catfish (Pterygoplichthys multiradiatus) in Florida. Florida Scientist 73: 122-137.

Gutierre SMM, Schofield PJ, Prodocimo V (in press) Salinity and temperature tolerance of an emergent alien species, the Amazon fish Astronotus ocellatus. Hydrobiologia.

Idelberger CF, Stafford CJ, Erickson SE (2011) Distribution and abundance of introduced fishes in Florida's Charlotte Harbor estuary. Gulf and Caribbean Research 23: 13-22.

Jennings DP (1986) Characterization of a localized Jack Dempsey, Cichlasoma octofasciatum, population in Alachua County, Florida. Florida Scientist 49: 255-259.

Kaplan EL, Meier P (1958) Nonparametric estimation from incomplete observations. Journal of the American Statistical Association 53: 457-481. doi: 10.1080/01621459.1958.10501452

Kline JL, Loftus WF, Kotun K, Trexler JC, Rehage JS, Lorenz JJ, Robinson M (2013) Recent fish introductions into Everglades National Park: an unforeseen consequence of water management? Wetlands 34: 175-187. doi: 10.1007/s13157-012-0362-0 
Kolar CS, Lodge DM (2002) Ecological predictions and risk assessment for alien fishes in North America. Science 298: 1233-1236. doi: 10.1126/science.1075753

Langston JN, Schofield PJ, Hill JE, Loftus WF (2010) Salinity tolerance of the African jewelfish Hemichromis letourneuxi, a non-native cichlid in south Florida (USA). Copeia, 475-480. doi: 10.1643/CP-09-069

Mol JH (1994) Effects of salinity on distribution, growth and survival of three Neotropical armoured catfishes (Siluriformes_Callichthyidae). Journal of Fish Biology 45: 763-776.

Obordo CO, Chapman LJ (1997) Respiratory strategies of a non-native Florida cichlid, Cichlasoma octofasciatum. Florida Scientist 60: 40-52.

Pelicice FM, Agostinho AA (2009) Fish fauna destruction after the introduction of a non-native predator (Cichla kelberi) in a Neotropical reservoir. Biological Invasions 11: 1789-1801. doi: 10.1007/s10530-008-9358-3

Peterson MS, Comyns BH, Rakocinski CF (2004) Defining the fundamental physiological niche of young estuarine fishes and its relationship to understanding distribution, vital metrics, and optimal nursery conditions. Environmental Biology of Fishes 71: 143-149. doi: 10.1007/s10641-004-0302-1

Quist MC, Guy CS, Stephen JL (2003) Recruitment dynamics of walleyes (Stizostedion vitreum) in Kansas reservoirs: generalities with natural systems and effects of a centrarchid predator. Canadian Journal of Fisheries and Aquatic Sciences 60: 830-839. doi: 10.1139/f03-067

Rainboth WJ (1996) FAO Species Identification Field Guide for Fishery Purposes: Fishes of the Cambodian Mekong. Food and Agriculture Organisation of the United Nations, Rome.

Rehage JS, Dunlop KL, Loftus WL (2009) Antipredator responses by native mosquitofish to non-native cichlids: an examination of the role of preynaiveté. Ethology 115: 1046-105. doi: 10.1111/j.1439-0310.2009.01694.x

Rejmánek M, Richardson DM, Barbour MG, Crawley MJ, Hrusa GF, Moyle PB, Randall JM, Simberloff D, Williamson M (2002) Biological invasions: politics and the discontinuity of ecological terminology. Bulletin of the Ecological Society of America 83: 131-133.

Savage IR (1956) Contributions to the theory of rank order statistics - the two-sample case. Annals of Mathematical Statistics 27: 590-615. doi: 10.1214/aoms/1177728170

Schofield PJ, Huge DH (2011) Low-temperature tolerance of two non-native fishes (Hoplosternum littorale [Hancock 1828], Cichlasoma bimaculatum [Linnaeus 1758]) established in Florida. Florida Scientist 74: 73-83.

Schofield PJ, Loftus WF (2014) Non-native fishes in Florida freshwaters: A literature review and synthesis. Reviews in Fish Biology and Fisheries. doi: 10.1007/s11160-014-9373-7

Schofield PJ, Pecora DH (2013) Croaking gourami, Trichopsis vittata (Cuvier, 1831), in Florida, USA. BioInvasions Records 2: 247-251. doi: 10.3391/bir.2013.2.3.12

Schofield PJ, Loftus WF, Brown ME (2007) Hypoxia tolerance of two centrarchid sunfishes and an introduced cichlid in karstic Everglades wetlands of southern Florida, U.S.A. Journal of Fish Biology 71 (Sup D): 87-99. doi: 10.1111/j.1095-8649.2007.01686.x

Schofield PJ, Loftus WJ, Fontaine JA (2009) Salinity effects on behavioural response to hypoxia in the non-native Mayan cichlid (Cichlasoma urophthalmus) from Florida Everglades wetlands. Journal of Fish Biology 74: 1245-1258. doi: 10.1111/j.1095-8649.2009.02192.x 
Schofield PJ, Loftus WF, Kobza RM, Cook MI, Slone DH (2010) Tolerance of nonindigenous cichlid fishes (Cichlasoma urophthalmus, Hemichromis letourneuxi) to low temperature: laboratory and field experiments in south Florida. Biological Invasions 12: 2441-2457. doi: 10.1007/s10530-009-9654-6

Shafland PL (1996) Exotic fishes of Florida - 1994. Reviews in Fisheries Science 4: 101-122. doi: 10.1080/10641269609388581

Shafland PL, Pestrak JM (1982) Lower lethal temperatures for fourteen non-native fishes in Florida. Environmental Biology of Fishes 7: 149-156. doi: 10.1007/BF00001785

Shafland PL, Gestring KB, Stanford MS (2008) Florida's exotic freshwater fishes - 2007. Florida Scientist 71: 220-245.

Stauffer JR Jr, Boltz SE (1994) Effect of salinity on the temperature preference and tolerance of age-0 Mayan cichlids. Transactions of the American Fisheries Society 123: 101-107. doi: 10.1577/1548-8659(1994)123<0101:EOSOTT >2.3.CO;2

Suresh AV, Lin CK (1992) Tilapia culture in saline waters: a review. Aquaculture 106: 201-226. doi: 10.1016/0044-8486(92)90253-H

Thompson KA, Hill JE, Nico LG (2012) Eastern mosquitofish resists invasion by nonindigenous poeciliids through agonistic behaviors. Biological Invasions 14: 1515-1529. doi: 10.1007/s10530-012-0176-2

Vitule JRS, Freire CA, Simberloff D (2009) Introduction of non-native freshwater fish can certainly be bad. Fish and Fisheries 10: 98-108. doi: 10.1111/j.1467-2979.2008.00312.x

Weber MJ, Brown ML (2011) Relationships among invasive common carp, native fishes and physicochemical characteristics in upper Midwest (USA) lakes. Ecology of Freshwater Fish 20: 270-278. doi: 10.1111/j.1600-0633.2011.00493.x

USGS-NAS (2014) US Geological Survey: Nonindigenous Aquatic Species database. http:// nas.er.usgs.gov 